\title{
Legitima apărare față de transmiterea unei boli infectocontagioase ${ }^{1}$
}

Av. drd. Dorel Herinean

Facultatea de Drept, Universitatea din București

Rezumat: Dincolo de măsurile de protecție pe care le ia statul pentru a preîntâmpina îmbolnăvirea cetățenilor, legislația penală nu exclude dreptul fiecăruia de a se apăra împotriva unor conduite prin care se încearcă sau se creează posibilitatea transmiterii unor boli. Articolul îşi propune să studieze modalitatea de aplicare a legitimei apărări față de un atac constând în incercarea de transmitere a unei boli infectocontagioase, studiind toate condițiile acestei cauze justificative, atât cele arondate atacului, cât și cele necesare ripostei, astfel încât să se ajungă la concluzia incidenței sau, din contră, a inaplicabilității ei în anumite situații.

Cuvinte-cheie: cauza justificativă, legitima apărare, zădărnicirea combaterii bolilor, boală infectocontagioasă

\section{The legitimate defence against the transmission of an infectious disease}

Abstract: Apart from the protection measures taken by the state to prevent the illness of citizens, criminal law does not exclude the right of each person to defend himself against conducts that attempt or create the possibility of transmitting diseases. The paper aims to study how the legitimate defence applies in cases of an attack consisting in the attempt to transmit an infectious disease, studying all the conditions of this justification cause, both those related to the attack and those necessary for the defence, so as to reach the conclusion of the incidence or, conversely, of the inapplicability in certain situations.

Keywords: justification cause, legitimate defence, transmission of infectious disease, preventing the fighting of diseases

\section{Situatia premisă}

Unul dintre cele mai importante instincte umane este cel de auto-conservare, omul având nevoia să se protejeze față de posibili factori externi dăunători pentru a putea supraviețui în orice

\footnotetext{
${ }^{1}$ Prezentul material pornește de la prelegerea cu tema „Considerente privind cauzele justificative pe perioada stării de urgență”, susținută pe 31 martie 2020 la Conferința online „Urgența în Drept”, organizată de Facultatea de Drept, Universitatea din București. Înregistrarea video este disponibilă pe Canalul Youtube al Facultătii de Drept.
} 
condiții. Legiuitorul penal nu a putut să ignore această nevoie a omului, drept pentru care a creat posibilitatea ca, atunci când o persoană se află în fața unui atac, aceasta să poată riposta.

Perioada actuală de stare de urgență, cauzată de pandemia COVID-19 creează situații nemaî̂ntâlnite în care va trebui să se verifice aplicabilitatea unor instituții consacrate în practica și doctrina juridică. Una dintre aceste instituţii este cauza justificativă a legitimei apărări, care, de regulă, este analizată și incidentă în cazul infracțiunilor comise cu violență sau contra patrimoniului.

Astfel, prezentul articol își propune să analizeze în ce măsură poate fi incidentă legitima apărare față de o acțiune prin care se încearcă sau se creează posibilitatea transmiterii unei boli infectocontagioase (în acest context, COVID-19) cum ar fi tusea, strănutul sau alte forme de expectorație ori acțiuni prin care este posibilă transmiterea unei boli infectocontagioase, cum ar fi atingerea persoanei cu un obiect contaminat ori infectat (denumită în continuare ,situația premisă”).

\section{Prezentarea cauzei justificative}

Cauza justificativă a legitimei apărări este definită la art. 19 C. pen. ${ }^{2}$, condițiile de aplicare ale acesteia fiind reglementate la alin. (2). După cum se poate observa, condițiile sunt împărțite în două categorii, respectiv cele referitoare la acțiunea calificată ca atac și acțiunea de apărare.

În continuare, vom analiza condiţiile menţionate anterior pentru existența unei stări de legitimă apărare și a unei riposte care să fie protejate de lege, făcând mențiuni particulare cu privire la aceste situații-premisă.

\section{Conditii cu privire la atac}

Pentru a putea discuta de legitima apărare, atacul trebuie să fie material, direct, imediat și injust. Astfel cum se arată și în doctrină, atacul poate fi realizat atât sub formă de acțiune, cât și de inacțiune și trebuie îndreptat împotriva celui care se apără, a altuia ori a unui interes general, punând totodată în pericol drepturile, interesele ori persoana celui atacat sau interesul general ${ }^{3}$.

\subsection{Caracterul material}

Literatura de specialitate arată că un atac poate fi considerat material atunci când pune în

2 (1) Este justificată fapta prevăzută de legea penală săvârșită în legitimă apărare.

(2) Este în legitimă apărare persoana care săvârșește fapta pentru a înlătura un atac material, direct, imediat şi injust, care pune în pericol persoana sa, a altuia, drepturile acestora sau un interes general, dacă apărarea este proporțională cu gravitatea atacului.

(3) Se prezumă a fi în legitimă apărare, în condițiile alin. (2), acela care comite fapta pentru a respinge pătrunderea unei persoane într-o locuință, încăpere, dependință sau loc împrejmuit ținând de aceasta, fără drept, prin violență, viclenie, efracție sau alte asemenea modalități nelegale ori în timpul nopții.

${ }^{3}$ L. V. Lefterache, Drept penal, Partea generală. Curs pentru studenții anului II, Ediția a II-a, editura Hamangiu, București, 2018, p. 191. 
pericol în mod fizic valorile sociale ocrotite împotriva cărora se desfăşoară ${ }^{4}$, obiectivându-se în acțiuni fizice, mijloace sau instrumente apte să producă o modificare materială valorii sociale ocrotite $^{5}$.

Totodată, în doctrină se menționează că legea exclude posibilitatea atacurilor prin acțiuni nonviolente, care nu prezintă pericol fizic ${ }^{6}$. Survine astfel întrebarea dacă ar putea fi încadrate ca atacuri materiale acțiunile din situația premisă, respectiv tusea intenționată, strănutul intenționat îndreptat spre o persoană, alte forme de expectorație sau atingerea acesteia cu un obiect contaminat ori infectat, existând un risc real de transmitere a bolii infectocontagioase prin aceste modalități.

Din punctul nostru de vedere, este vorba de o acțiune aparent non-violentă, neproducându-se o suferință fizică imediată. Totuși, un astfel de comportament poate crea un pericol fizic pentru persoana atacată, dat fiind riscul de îmbolnăvire, cu suferințele fizice inerente. De altfel, în doctrină se admite posibilitatea exercitării atacului prin substanțe narcotice ${ }^{7}$, astfel încât, mutatis mutandis, nu vedem vreun impediment pentru a reține caracterul material al atacului prin transmiterea unei boli infectocontagioase.

Un argument în plus este și afirmația unor autori care arată că această condiție a atacului material este subliniată pentru a îl diferenția de atacul verbal sau scris, care nu va putea fi respins prin căi de fapt și nu dă dreptul unei riposte legitime ${ }^{8}$. Așadar, nefiind vorba de un atac verbal sau scris și având în vedere și consecințele pe care le poate produce transmiterea unei boli infectocontagioase, considerăm că o astfel de acțiune ar trebui să se subsumeze unui atac material.

\subsection{Caracterul direct}

Această caracteristică a atacului presupune necesitatea de a pune în pericol nemijlocit valorile împotriva căreia se îndreaptă9 . Atacul prezentat în situaţia premisă are un caracter ofensiv raportat la două valori sociale: sănătatea persoanei împotriva căreia se îndreaptă acțiunile, ca valoare socială individuală și sănătatea publică, dat fiind caracterul de boală infectocontagioasă.

Pentru a putea stabili dacă există un caracter direct sau nu, se impune precizarea că pericolul vizează transmiterea bolii infectocontagioase, iar nu eventuala apariţie a simptomelor acesteia, care variază ca durată în funcție de perioada de incubare a virusului, putând exista și persoane infectate asimptomatice. Așadar, pentru reținerea caracterului direct al atacului, nu este necesar ca persoana

\footnotetext{
${ }^{4}$ Ibidem.

${ }^{5}$ C-tin. Mitrache, C. Mitrache, Drept penal român, Ediția a III-a, editura Universul Juridic, București, 2019 , p. 180.

${ }^{6}$ L. V. Lefterache, op. cit., p.192.

${ }^{7}$ F. Streteanu, D. Nițu, Drept penal. Partea generală, Volumul 1, editura Universul Juridic, București, 2014 , p. 354.

${ }^{8}$ C-tin. Mitrache, C. Mitrache, op. cit., p. 180-181.

${ }^{9}$ L. V. Lefterache, op. cit., p. 193.
} 
să se îmbolnăvească efectiv ${ }^{10}$, ci doar să existe posibilitatea transmiterii infecției către aceasta prin modalitățile de infectare cunoscute.

Astfel, caracterul direct pare a fi îndeplinit raportat la ambele valori sociale posibil lezate, neexistând un obstacol care să poată împiedica afectarea acestora, în contextul în care existența unui obstacol este criteriul care, de regulă, se utilizează pentru verificarea acestui caracter.

Se poate pune problema existenței unor măsuri de protecție care să asigure persoana atacată de faptul că nu ar putea fí infectată, cum ar fi purtarea măștii, mănușilor, vizierelor sau chiar a unui combinezon complet.

În opinia noastră, în lipsa unui echipament adecvat și complet care să preîntâmpine transmiterea bolii infectocontagioase, va exista caracterul direct al atacului, dat fiind pericolul nemijlocit care vizează sănătatea persoanei, chiar dacă, parțial, există o măsură de protecție care ar putea diminua șansele producerii acestuia. A contrario, în cazul persoanei complet și adecvat echipate, aceasta nu va putea invoca existența unui atac direct împotriva sănătății sale, o eventuală ripostă nefiind exercitată sub imperiul legitimei apărări, ci eventual în condițiile circumstanței atenuante a provocării, prevăzute la art. 75 alin. (1) lit. a) C. pen.

\subsection{Caracterul imediat}

Atacul este imediat dacă pericolul pentru valoarea socială este actual (s-a produs deja) ori iminent (este pe cale să se ivească) ${ }^{11}$, fiind avut în vedere raportul de timp dintre atac și starea de pericol $^{12}$. Dat fiind cele descrise supra, pericolul vizează transmiterea bolii infectocontagioase (infectarea persoanei), iar nu apariţia simptomatologiei ori efectelor acesteia, fapt pentru care, considerăm că această condiție va fi îndeplinită atunci când s-a exercitat una dintre acțiunile descrise în situația premisă (tuse, strănut, alte expectorații sau acțiuni prin care se poate transmite boala) sau când este în imediata vecinătate temporală (de exemplu, persoana trage aer în piept pentru a se pregăti să tușească, după o avertizare prealabilă a victimei cu privire la exercitarea acțiunii). Acestea vor fi momentele de la care se poate considera că există un atac având caracter imediat.

În analiza caracterului imediat este important și momentul până la care acesta există, identificat ca epuizarea atacului ${ }^{13}$. Astfel, din momentul în care atacul încetează, nu va mai fi îndeplinită această condiție pentru reținerea legitimei apărări. Legitima apărare nu a fost concepută pentru a justifica acțiunile vindicative, ci pentru a justifica faptele necesare îndepărtării sau

\footnotetext{
${ }^{10}$ Mai ales că în cazul majorității bolilor, simptomele sau efectele nu apar instantaneu și chiar pot exista persoane imune, care să nu cunoască acest lucru. Această afirmație nu se pretinde a avea vreo bază medicală, fiind bazată pe cunoștințe generice doar.

${ }^{11}$ L. V. Lefterache, op. cit., p. 193.

${ }^{12}$ C-tin. Mitrache, C. Mitrache, op. cit., p. 181.

${ }^{13}$ L. V. Lefterache, op. cit., p. 194.
} 
prevenirii unei stări de pericol, motiv pentru care din momentul în care nu mai există atacul cauzator de pericol, chiar dacă pericolul a fost produs deja, nu va mai fi incidentă această cauză justificativă.

Din aceste motive, atacul constând într-o acțiune singulară, instantanee, va avea un caracter imediat și va permite existența stării de legitimă apărare numai dacă este precedat de o amenințare (din partea persoanei atacatoare) sau avertizare (din partea unui terț observator) în acest sens, iar executarea lui este începută sau iminentă.

În lipsa unei avertizări sau amenințări, pentru a exista un atac imediat, de tipul celui prezentat în situația premisă, este nevoie ca acțiunea să fie repetitivă și în curs de executare (de exemplu, tuse repetată îndreptată împotriva unei persoane). Apărarea va putea interveni până la momentul la care pericolul este imediat, astfel încât nu va putea interveni, după cum am arătat, din momentul în care acțiunile de expectorație au încetat.

\subsection{Caracterul injust}

Nu în ultimul rând, atacul trebuie să aibă caracter injust, adică persoana care exercită atacul să nu poată justifica existența acestuia utilizând un temei legal sau autorizarea legii ${ }^{14}$. Deși poate părea că atacul trebuie să constea într-o faptă prevăzută de legea penală, în doctrină se precizează că nu este necesar acest lucru ${ }^{15}$, deși în cele mai multe cazuri este sau va fi vorba de fapte prevăzute de legea penală sau chiar infracțiuni.

$\mathrm{Cu}$ toate acestea, în situația premisă discutăm de infracțiunea de zădărnicirea combaterii bolilor, prevăzută și sancționată de art. 352 C. pen ${ }^{16}$, fiind vorba de o acțiune prin care se urmărește sau acceptă transmiterea bolii infectocontagioase prin unul din mijloacele cunoscute ca apte să

\footnotetext{
${ }^{14}$ F. Streteanu, D. Nițu, op. cit., p. 358.

15 Idem, p. 361.

${ }^{16}$ Art. 352 C. pen. Zădărnicirea combaterii bolilor
}

(1) Nerespectarea măsurilor de carantină sau de spitalizare dispuse pentru prevenirea sau combaterea bolilor infectocontagioase se pedepsește cu închisoare de la 6 luni la 3 ani sau cu amendă.

(2) Nerespectarea măsurilor privitoare la prevenirea sau combaterea bolilor infectocontagioase, dacă fapta a avut ca urmare răspândirea unei asemenea boli, se pedepsește cu închisoare de la unu la 5 ani.

(3) Transmiterea, prin orice mijloace, a unei boli infectocontagioase de către o persoană care știe că suferă de această boală se pedepsește cu închisoare de la 2 la 7 ani și interzicerea exercitării unor drepturi.

(4) Dacă fapta prevăzută în alin. (2) este săvârșită din culpă, pedeapsa este închisoarea de la 6 luni la 3 ani sau amenda. (5) Dacă prin faptele prevăzute în alin. (1) și (2) s-a produs vătămarea corporală a uneia sau mai multor persoane, pedeapsa este închisoarea de la 2 la 7 ani și interzicerea exercitării unor drepturi, iar dacă s-a produs moartea uneia sau mai multor persoane, pedeapsa este închisoarea de la 5 la 12 ani și interzicerea exercitării unor drepturi.

(6) Dacă prin fapta prevăzută în alin. (3) s-a produs vătămarea corporală a uneia sau mai multor persoane, pedeapsa este închisoarea de la 3 la 10 ani și interzicerea exercitării unor drepturi, iar dacă s-a produs moartea uneia sau mai multor persoane, pedeapsa este închisoarea de la 7 la 15 ani și interzicerea exercitării unor drepturi.

(7) Dacă prin fapta prevăzută în alin. (4) s-a produs vătămarea corporală a uneia sau mai multor persoane, pedeapsa este închisoarea de la unu la 5 ani și interzicerea exercitării unor drepturi, iar dacă s-a produs moartea uneia sau mai multor persoane, pedeapsa este închisoarea de la 2 la 7 ani și interzicerea exercitării unor drepturi.

(8) Tentativa la infracțiunea prevăzută la alin. (3) se pedepsește.

(9) Prin carantină se înțelege restricția activităților și separarea de alte persoane, în spatii special amenajate, a persoanelor bolnave sau care sunt suspecte de a fi bolnave, intr-o manieră care să prevină posibila răspândire a infecției sau contaminării. 
producă acest rezultat. Astfel cum se arată și în doctrină ${ }^{17}$, în cazul intervenției efectuate de o terță persoană, nu este relevant în analiza caracterului injust dacă victima dorea să se apere sau nu împotriva atacului ${ }^{18}$.

Analizând modalitățile de comitere ale acestei infracțiuni, fără însă a intra în discuția acestui subiect extrem de interesant ${ }^{19}$, considerăm că ar putea fi incidente normele de incriminare de la alin. (2) și (3).

Norma de incriminare de la art. 352 alin. (3) C. pen. are un subiect activ special, respectiv „persoana care știe că suferă” de o boală infectocontagioasă. Survine astfel întrebarea dacă persoana care exercită atacul trebuie să fie bolnavă sau este suficient ca măcar să fie percepută ca bolnavă. Dacă persoana este bolnavă și cel care se apără cunoaște acest lucru, nu există dubii că ar fi îndeplinită condiția caracterului injust. Dacă atacatorul adresează, anterior sau în timpul atacului, o amenințare cu privire la posibilitatea îmbolnăvirii, nu va mai conta starea de sănătate a acestuia, persoana care exercită apărarea putând percepe fapta materială a autorului (iar nu strict amenințarea, după cum am arătat supra) ca injustă, existând astfel situaţia de legitimă apărare, eventual însoțită de o eroare de fapt, doctrina admițând posibilitatea existenței acesteia ${ }^{20}$.

Raportat la situaţia în care persoana crede că este infectată, acest lucru nefiind adevărat, dar încearcă totuşi transmiterea infecției către o altă persoană, aderăm la opinia formulată în doctrină potrivit căreia fapta va fi calificată ca tentativă idonee, conform art. 352 alin. (8) C. pen., dacă

\footnotetext{
${ }^{17}$ C-tin. Mitrache, C. Mitrache, op. cit., p. 183.

${ }^{18}$ De altfel, consimțământul persoanei vătămate nu înlătură caracterul ilicit al faptei de zădărnicirea combaterii bolilor. Pentru mai multe detalii pe acest subiect, a se vedea D. Herinean, Cauza justificativă a consimțământului cu privire la transmiterea unor boli infectocontagioase, publicat în data de 06.04.2020 în secțiunea Forum juridic al Analelor Universităţii din București, disponibil pe https://drept.unibuc.ro/Forum-juridic-s938-ro.htm, accesat în data de 23.04.2020.

${ }^{19}$ Pentru analize extensive ale acestei infracțiuni, relevante și în contextul prezentului articol, a se vedea G.-A. Lazăr, Modificările propuse pentru modificarea Codului Penal în vederea combaterii răspândirii coronavirusului, publicat în data de 20.03.2020 în secțiunea Forum juridic al Analelor Universității din București, disponibil pe https://drept.unibuc.ro/Forum-juridic-s938-ro.htm; G.-A. Lazăr, O necesară precizare în raport de forma de vinovăție cu care sunt săvârșite formele agravate ale infracțiunii de zădărnicire a combaterii bolilor, publicat în data de 02.04.2020 în secțiunea Forum juridic al Analelor Universității din București, disponibil pe https://drept.unibuc.ro/Forum-juridic-s938-ro.htm; G. Zlati, D.V. Leordean, Infracțiunea privind zădărnicirea combaterii bolilor (art. 352 Cod penal). Despre ințelegerea textului de incriminare şi posibilitatea efectuării unei expertize genetice, publicat în 17.03.2020, disponibil pe https://www.penalmente.eu/; R. Slăvoiu, Modificarea dispozitiilor art. 352 Cod penal prin O.U.G. nr. 28/200. Sau, de ce este periculoasă supranormarea, publicat în data de 23.03.2020, disponibil pe https://www.juridice.ro/; G.-C. Ioan, G. Zlati, Pandemia covid-19 şi răspunderea penală (i): calificarea juridică şi constituționalitatea O.U.G. $n r$. 28/2020. Raportul cu răspunderea contravențională, publicat în 03.04.2020, disponibil pe https://www.penalmente.eu/; D. Pârgaru, Observații critice în legătură cu modificările aduse art. 352 C.pen. în contextul pandemiei COVID-19, publicat în data de 08.04.2020 în secțiunea Forum juridic al Analelor Universității din București, disponibil pe https://drept.unibuc.ro/Forum-juridic-s938-ro.htm, toate consultate în data de 23.04.2020.

${ }^{20}$ L. V. Lefterache, op. cit., p. 197.
} 
mijloacele de transmitere sunt apte să realizeze transmiterea ${ }^{21}$. Consecința caracterizării ca tentativă idonee este reținerea caracterului injust al atacului și într-o astfel de ipoteză. Mutatis mutandis, considerăm că soluția este aceeași dacă persoana care exercită atacul nu știe cu certitudine că este bolnavă, dar prezintă simptome specifice bolii infectocontagioase, simptome care sunt percepute și de către persoana care se apără, în acest caz putând fi vorba de o intenție indirectă ${ }^{22}$ raportat la transmiterea bolii. Soluția poate fi însă criticabilă raportat la subiectul activ special al acestei infracțiuni, persoană care știe că suferă de o boală. Or, caracterul de ,persoană care știe că suferă ”, nu este echivalentă cu noțiunea de ,persoană care acceptă că s-ar putea să sufere”, putându-se considera că ar fi o analogie în defavoarea inculpatului. Totuși, eroarea de fapt invincibilă asupra existenței stării de legitimă apărare ar putea produce efectele prevăzute la ar. 35 alin. (5) C. pen., dacă persoana care se apără nu avea cum să își dea seama, în situația concretă, că atacatorul nu este bolnav.

Parametrii discuției se schimbă atunci când persoana care se apără nu are indicii privitoare la starea de sănătate a atacatorului, care nici nu prezintă simptome care să indice o posibilă infectare, dar exercită o acțiune de tipul celor descrise în situația premisă. În aceste cazuri, chiar dacă putem fi de acord cu existența caracterul injust, acesta subsumându-se eventual infracțiunii de ameninţare, nu va exista caracterul material al atacului.

Deși situația premisă exclude această ipoteză, vom menționa că o tuse sau un strănut care, fără a putea fi perceput ca intenţionat, se îndreaptă împotriva unei persoane nu are caracterul injust necesar stării de legitimă apărare, dat fiind că nici măcar nu poate fi calificată ca un atac. Totuşi, condiția care arată cel mai clar lipsa stării de legitimă apărare în această situație este caracterul imediat, dat fiind că o tuse sau un strănut singular, neintenționat, nu ar constitui un atac în curs de desfășurare.

\subsection{Obiectul atacului și starea de pericol creată}

Atacul prezentat în situaţia premisă se îndreaptă, în primul rând, împotriva dreptului la sănătate al persoanei atacate, prin posibilitatea infectării acesteia și, în al doilea rând, împotriva interesului general al sănătății publice privind împiedicarea răspândirii bolilor infectocontagioase. Totuşi, dacă analizăm starea de pericol prin prisma normei de incriminare care am stabilit că va fi incidentă în general și a obiectului juridic al acesteia, se va constata că valoarea socială principală ocrotită este sănătatea publica, iar sănătatea persoanei individuale ar putea fi protejată ca valoare

\footnotetext{
${ }^{21}$ G.-A. Lazăr, Modificările..., cit. supra. Autorul citat trimite la o altă lucrare în care se detaliază motivația reținerii, în aceste cazuri, unei tentative idonee, iar nu a unei fapte putative, respectiv G.-A. Lazăr, Infracțiunea putativă. Studiu de caz al consecințelor erorii subiectului infracțiunilor de corupție, publicată în A.U.B.D., anul XVI/2017, p. 169.

${ }^{22}$ În același sens al posibilității comiterii modalității de la art. 352 alin. (3) C. pen. cu intenție indirectă, a se vedea G. A. Lazăr, Modificările propuse..., cit. supra ; D. Pârgaru, cit. supra; R. Slăvoiu, cit. supra.
} 
socială secundară.

Din punctul nostru de vedere, soluția ar putea depinde de persoana care efectuează apărarea, respectiv dacă pentru aceasta este mai importantă apărarea sănătăţii unei persoane anume sau a sănătății publice, putând avea în vedere aici și natura atacului. În doctrină se arată că pot fi atacate și interese generale care nu au un titular determinat, dar aparțin unei colectivități în ansamblu, reglementarea din dreptul nostru permițând existența stării de legitimă apărare în cazul în care atacul vizează un interes general (precum sănătatea publică), chiar în lipsa unei victime directe ${ }^{23}$.

Ținând cont de toate acestea și având în vedere că oricum, în situația premisă, există și o victimă directă, reiese că indiferent de soluția adoptată, sunt îndeplinite condițiile cu privire la starea de pericol creată pentru una dintre valorile sociale de la art. 19 alin. (2) C. pen.

\section{Conditii cu privire la apărare}

Atunci când toate condițiile cu privire la atac sunt îndeplinite, izvorăște o situație de legitimă apărare, în temeiul căreia există dreptul la exercitarea unei acțiuni (ori inacțiuni) de apărare împotriva persoanei atacatoare, fie de către persoana împotriva căreia se îndreaptă atacul, fie de către un terț. Totuși, la fel ca și atacul, apărarea trebuie să se circumscrie anumitor condiții, reținerea cauzei justificative neputând fi exercitată în mod arbitrar sau justifica orice infracțiune comisă. Astfel, este necesar ca apărarea, precedată de atac, să fie realizată printr-o faptă prevăzută de legea penală îndreptată împotriva agresorului, necesară pentru înlăturarea atacului și proporțională cu $\operatorname{acesta}^{24}$.

\subsection{Natura de faptă prevăzută de legea penală}

Prima condiție este ca apărarea să ia forma unei fapte prevăzute de legea penală, comisă atât prin acțiune, cât și prin omisiune ${ }^{25}$. După cum se precizează în doctrină, fapta poate fi comisă atât cu intenție, cât și din culpă, forma de vinovăție nefiind relevantă raportat la reținerea stării de legitimă apărare, atâta timp cât acțiunea sau omisiunea sunt desfășurate în contextul existenței unui atac, chiar dacă rezultatul este produs din culpă ${ }^{26}$.

Motivarea existenței acestei condiții este că, în lipsa unei fapte prevăzute de legea penală, nu am putea discuta despre cauza justificativă a legitimei apărări. Așadar, în situația premisă vom putea discuta despre existența unei apărări efectuate într-o situație de legitimă apărare doar dacă se comite o faptă prevăzută de legea penală de către cel atacat sau de persoana care intervine.

\footnotetext{
${ }^{23}$ F. Streteanu, D. Nițu, op. cit., p. 362-363.

${ }^{24}$ L. V. Lefterache, op. cit., p. 196.

${ }^{25}$ L. V. Lefterache, op. cit., p. 197.

${ }^{26}$ L. V. Lefterache, op. cit., p. 198; F. Streteanu, D. Nițu, op. cit., p. 365.
} 


\subsection{Existența unui atac anterior}

După cum am mai arătat, pentru ca o ripostă să fie justificată aceasta trebuie să fie manifestată în vederea înlăturării unui atac care produce un pericol actual sau iminent ${ }^{27}$. Această condiție este în oglindă cu cea a caracterului imediat al atacului, trebuind să existe un atac în curs de desfășurare împotrivă căruia să se îndrepte acțiunea de apărare, toate cele menționate în acel context aplicânduse mutatis mutandis.

\subsection{Riposta împotriva agresorului}

Următoarea condiție referitoare la apărare este ca aceasta să se îndrepte împotriva celui care exercită atacul, putând viza viaţa, sănătatea, sau libertatea acestuia ${ }^{28} . \mathrm{Cu}$ privire la posibilitatea exercitării apărării împotriva bunurilor, în doctrină s-a exprimat opinia că ar fi justificată și o astfel de apărare dacă este de natură a opri atacul, dându-se exemplul zgârierii unei vaze de o valoare deosebită pentru a distrage atenția autorului atacului, care ar fi nevoit să oprească atacul pentru a își salva bunul ${ }^{29}$.

În cazul situației premisă, acțiunea ar trebui îndreptată împotriva persoanei care tușește, strănută sau încearcă transmiterea bolii prin alte mijloace. Totuși, putem imagina situații în care acțiunea s-ar îndrepta împotriva unui animal asupra căruia atacatorul are control, de exemplu în cazul în care animalul respectiv este infectat cu o boală infectocontagioasă transmisibilă la oameni, iar atacul este exercitat prin intermediul acestuia. Având în vedere că doctrina admite posibilitatea îndreptării atacului și împotriva animalului dacă atacul este realizat prin asmuțirea acestuia ${ }^{30}$, considerăm că soluția este aplicabilă și în situaţia analizată.

\subsection{Caracterul necesar pentru înlăturarea atacului}

Această cerință presupune ca apărarea exercitată să fie nu doar necesară, cât și aptă să înlăture atacul, nefiind însă imperativ ca modalitatea aleasă să fie singura posibilitate pe care o avea la dispoziție cel care se apără $\breve{31}^{31}$. Astfel, dat fiind faptul că atacul este imputabil celui împotriva căruia se îndreaptă apărarea, legea permite exercitarea unei riposte chiar dacă, de exemplu, exista posibilitatea de a fugi sau de a preveni într-un mod neprevăzut de legea penală atacul ori rezultatul, atâta timp cât, astfel cum vom arăta, este întrunit și caracterul proporțional.

Ținând cont de cele arătate în cadrul analizei caracterului imediat al atacului, ne întrebăm în ce măsură ar putea fi considerată necesară o ripostă în ipoteza exercitării celei de-a doua acțiuni prin

\footnotetext{
${ }^{27}$ L. V. Lefterache, op. cit., p. 197.

${ }^{28}$ C-tin. Mitrache, C. Mitrache, op. cit., p. 184.

${ }^{29}$ F. Streteanu, D. Nițu, op. cit., p. 366. Pentru opinia contrară, în sensul imposibilității exercitării unor acțiuni de apărare împotriva bunurilor unei persoane, a se vedea C-tin. Mitrache, C. Mitrache, op. cit., p. 184.

${ }^{30}$ F. Streteanu, D. Nițu, op. cit., p. 366.

${ }^{31}$ L. V. Lefterache, op. cit., p. 197.
} 
care se realizează atacul, reamintind că am susținut că (în lipsa unei amenințări prealabile) doar repetarea acțiunii ar putea oferi un caracter imediat atacului. Or, dacă prima acțiune a produs deja starea de pericol - posibilitatea transmiterii bolii infectocontagioase, pot exista dubii cu privire la caracterul necesar al ripostei ulterioare primei acțiuni, având în vedere că există deja un pericol potențial sau că este posibil ca deja boala infectocontagioasă să se fi transmis.

Totuși, nu putem fi de acord cu o astfel de susținere, întrucât pericolul de infectare crește, cel puțin la nivel teoretic, proporțional cu expunerea la factorii de risc, astfel încât repetarea acțiunii ar putea amplifica pericolul, chiar dacă acesta există deja, concluzia fiind în concordanță și cu caracterul imediat al pericolului.

Totodată, menționăm că nu considerăm că starea de pericol creată prin acțiunea din situația premisă cu privire la transmiterea unei boli infectocontagioase se află în categoria faptelor pentru care este posibilă înlăturarea ori diminuarea efectelor (așa numitele fapte cu rezultat reversibil), astfel încât să justifice o ripostă și după epuizarea atacului. Cum am susţinut și în cazul atacului, starea de legitimă apărare va înceta, în aceste cazuri, de îndată ce sunt epuizate acțiunile apte să transmită boala ori virusul.

\subsection{Caracterul proportional}

Ultima condiție arondată ripostei pentru reținerea stării de legitimă apărare este caracterul proporțional al acesteia față de atac, în lipsa acestuia discutând de cauza de neimputabilitate a excesului neimputabil (art. 26 alin. (1) C. pen.) sau de circumstanța atenuantă a depășirii limitelor legitimei apărări (art. 75 alin. (1) lit. b) C. pen.).

După cum se arată în doctrină, proporționalitatea trebuie să caracterizeze raportul de gravitate dintre consecințele produse ori apte să se producă prin fapta de apărare și consecințele care s-au produs sau s-ar fi produs prin fapta atacatorului ${ }^{32}$, privite în împrejurările concrete ale situației factuale. Vor fi avute în vedere și valorile sociale în conflict, mijloacele utilizate în atac și apărare, timpul și locul comiterii faptei precum și toate celelalte circumstanțe în care s-a desfășurat atacul ${ }^{33}$. Pornind de la această afirmație, considerăm că proporționalitatea unei riposte ar putea fi influențată și de existența stării de epidemie ori pandemie cu privire la o boală infectocontagioasă la momentul exercitării atacului (cum este în situația actuală, COVID-19), precum și a unor măsuri drastice luate de autorităţi (cum ar fi starea de urgență și restrângerile drepturilor individuale luate în această perioadă), acestea constituind circumstanţe care ar putea justifica un răspuns mai ferm împotriva atacului.

După cum am arătat, valorile puse în primejdie prin atacul descris în situaţia premisă sunt

\footnotetext{
${ }^{32}$ L. V. Lefterache, op. cit., p. 198.

${ }^{33}$ F. Streteanu, D. Nițu, op. cit., p. 370.
} 
sănătatea individuală a persoanei, precum și interesul general - sănătatea publică. Nu este necesar ca acțiunea de apărare să se îndrepte împotriva aceleiași valori sociale, nefiind trebuincioasă o identitate și nici măcar o similitudine între atac și apărare ${ }^{34}$. Totuși, o echivalență atac-apărare prin lezarea aceleiași valori sociale poate fi un indiciu cu privire la proporționalitatea apărării ${ }^{35}$.

Din aceste considerente și privind in abstracto raportul dintre valorile sociale, considerăm că faptele contra vieții nu vor putea fi justificate, de regulă, de atacul constând în acțiunile care lezează sănătatea în modalitatea prezentată în situația premisă, fie că este vorba de sănătatea individuală ori publică. Astfel nu considerăm că ar fi proporțională împușcarea persoanei care exercită un astfel de atac. Totuși, deviind puțin de la situația premisă, ne putem imagina situații în care ar putea exista o discuţie cu privire la proporționalitate chiar și pentru o acțiune de împușcare. De exemplu, dacă o persoană încearcă deversarea unui virus (sau a unui alt factor al unei boli infectocontagioase) în sistemul de aerisire al unui spațiu închis în care se află multe persoane, boală care s-ar răspândi foarte repede și cel mai probabil ar cauza decesul mai multor persoane, nu putem exclude de plano soluția reținerii stării de legitimă apărare pentru persoana care împușcă atacatorul pentru a preveni deversarea, fiind necesară însă analiza tuturor împrejurărilor în care această acțiune ar fi exercitată.

Ca exemple de apărări pe care le-am considera proporționale, sunt fapte care să se subsumeze normelor de loviri sau alte violențe (lovituri exercitate cu palma, pumnul, piciorul, îmbrânciri, ș.a.), amenințare, șantaj, lipsire de libertate, sau alte acțiuni îndreptate împotriva sănătății, integrităţii corporale ori libertății atacatorului, fără a exclude posibilitatea îndreptării acțiunii de apărare împotriva unor bunuri ale acestuia.

\section{Concluzii}

După cum se poate observa din toate cele prezentate anterior, legitima apărare va putea fi incidentă față de o acțiune care are un caracter material și prin care se transmite sau se încearcă transmiterea unei boli infectocontagioase, însă doar în anumite condiţii. O atenție deosebită va fi acordată condițiilor privitoare la caracterul material al atacului, nefiind suficientă amenințarea cu privire la transmiterea bolii, precum și la caracterul imediat al atacului, care să fie conturat fie pe o amenințare ori avertizare prealabilă urmată de o faptă, fie pe repetarea faptei. Astfel, o acțiune singulară, de orice natură, prin care se încearcă transmiterea unei boli infectocontagioase, nu va da naștere unei stări de legitimă apărare, dar ar atrage, oricum, răspunderea autorului acesteia. Atacul va fi injust, în opinia noastră, chiar dacă persoana care îl efectuează nu este bolnavă, însă prezintă simptome specifice bolii, care pot fi percepute de către cel care se apără și care pot crea acestuia

\footnotetext{
${ }^{34}$ L. V. Lefterache, op. cit., p. 198.

${ }^{35}$ C-tin. Mitrache, C. Mitrache, op. cit., p. 185.
} 
falsa reprezentare a existenței unei boli infectocontagioase.

Apărarea care se exercită, pentru a beneficia de efectele cauzei justificative și a nu avea un caracter ilicit, trebuie să fie comisă în timpul unui atac sau în momentul în care acesta este iminent, păstrându-și însă caracterul necesar chiar dacă s-a creat un pericol cu privire la infectare, atât timp cât acțiunile de atac continuă. Dacă atacul încetează, riposta nu va fi exercitată ca legitimă apărare ci, eventual, în stare de provocare, circumstanță atenuantă. Nu în ultimul rând, apărarea trebuie să fie proporțională cu atacul, îndreptându-se împotriva unor valori sociale de o importanță comparabilă cu cea a sănătății, cea vizată de atac, iar existența unei epidemii ori pandemii poate fi luată în considerare pentru justificarea unei reacții mai ferme împotriva unui atac de acest tip.

Materialul a fost publicat în revista online a Facultăţii de Drept, $\underline{\text { AUBD-Forum Juridic nr. }}$ $\underline{1 / 2020 .}$ 